\title{
UPTAKE OF ZN (II) BY AN INVASIVE WEED SPECIES PARTHENIUM HYSTEROPHORUS L.
}

\author{
SANGHAMITRA, K. ${ }^{1}$ - PRASADA RAO, P.V.V. ${ }^{2} *$ - NAIDU, G.R.K. ${ }^{1}$ \\ ${ }^{1}$ Department of Environmental Sciences, Sri Venkateswara University, Tirupati \\ ${ }^{2}$ Department of Andhra University, Visakhapatnam \\ (phone +91-0891-2844573) \\ *Corresponding author \\ e-mail: pvvprao.2008@rediffmail.com \\ (Received 24 $4^{\text {th }}$ April 2008; accepted $5^{\text {th }}$ January 2012)
}

\begin{abstract}
The ability of the invasive weed species Parthenium hysterophorus L. for the accumulation of the heavy metal $\mathrm{Zn}$ was studied in a greenhouse experiment. This study was aimed at identifying a metal tolerant species from natural vegetation and assess the phytoextraction potential of the plant. To compare metal concentrations in the aboveground biomass to those in roots and in soils along with nutrients. To study their effect on growth and comparison with metal amended soils treated with EDTA. The Zn accumulated by the test species was increased significantly after $0.1 \mathrm{~g} / \mathrm{kg}$ of EDTA was added to the medium. An increase in metal uptake with increase in test concentrations was observed. The metal uptake could effect the leaf pigments as it reduced with increase in metal exposures and time especially in EDTA treatment. This could be due to the accumulation of $\mathrm{Zn}$. The phosphorus levels were found to be low in higher uptakes of the plant. The BCFs of shoots and roots and TFs being greater than 1 shows the validity of the weed species for hyperaccumulation of the metal and can be a promising species for phytoextraction of heavy metals and remediation of metal contaminated soils which is economical and ecofriendly.
\end{abstract}

Keywords: Accumulation, EDTA, bioconcentration factor, translocation factor.

\section{Introduction}

Contamination of heavy metals represents one of the most pressing threat to water and soil resources as well as human health. Plants have been frequently used as indicators in the search of metal pollution or as accumulators for soil remediation called phytoremediation (Baker et al., 1994). Heavy metals may be bound or accumulated by particular plants, which may increase or decrease the mobility and prevent the leaching of heavy metals into groundwater. Growing plants can help to reduce heavy metals pollution. Plants can be easily monitored to ensure proper growth; and valuable metals can be reclaimed and reused through phytoremediation. One of the strategies of phytoremediation is phytoextraction i.e. uptake and accumulation of metals into plant shoots, which can then be harvested and removed from the site. It is necessary to use plants that can tolerate high levels of heavy metals. Certain heavy metals are also trace elements for e.g., $\mathrm{Zn}, \mathrm{Mn}, \mathrm{Mg}, \mathrm{Fe}, \mathrm{Cu}$, Mo and $\mathrm{Ni}$ which are essential in plant nutrition (micronutrient) but plants growing in a polluted environment can accumulate trace elements at high concentrations (Alloway, 1990; Hovmand et al., 1983; Huchabee et al., 1983; Kabata-Pendias and Pendias, 1992). Elevated levels of these metals in soil may lead to increased uptake by plants, because it depends on many different factors, such as soil metal bioavailability, plant growth and metal distribution to plant parts (John, 1973; John et al., 1972; Kuboi et al., 1986; Xian, 1989). 
Plants called hyperaccumulators are preferred for metal decontamination of soils because they take up 100 times the concentration of metals over other plants (Cunningham et al., 1995). They accumulate toxic metals through their roots and transport them to the stems or leaves. Researchers hope that these metal-scavenging plants, called hyperaccumulators, could be grown in contaminated soil and harvested like hay (Bennet et al., 2003; Lombi et al., 2001 O'Connor et al., 2003). The metal could then be recovered and recycled when burned and the ash collected (Comis, 1996).

Metals uptake by roots depends on both soil and plant factors (e.g. source and chemical form of elements in soil, $\mathrm{pH}$, organic matter, plant species, plant age etc.). Consequently, metal mobility and plant availability are very important when assessing the effect of soil contamination on plant metal uptake and related phytotoxic effects. The mobility and availability of heavy metals in the soil are generally low, especially when the soil is high in pH, clay and organic matter (Jung and Thornton, 1996; Rosselli et al., 2003). Interactions between metals occurring at the root surface and within the plant can affect uptake, as well as translocation and toxicity (Luo and Rimmer, 1995).

More than 400 plants are known as hyperaccumulators of metals, which can accumulate high concentration of metals into their aboveground biomass. The plants include trees, vegetables crops, grasses, and weeds. Weed species appear to be a good choice for metal accumulation studies since these hardy tolerant species can grow in most harsh conditions over large areas and give a good amount of biomass as a secondary product. It is important to use native plants to study metal accumulation because these plants are often better in terms of survival, growth and reproduction under environment. There has been a continuing interest in searching for native plants that are tolerant to heavy metals. Heavy metals can cause severe phytotoxicity, and may act as powerful force for the evolution of tolerant plant populations. Therefore, it is possible to identify metal-tolerant plant species from natural vegetation in field sites that are contaminated with various heavy metals.

Recently, chelating agents have been used as decontaminants in metal-polluted soils facilitating phytoextraction. Early studies showed that application of synthetic metal chelates such as Ethylenediamine tetraacetic acid (EDTA) to soils enhances $\mathrm{Pb}$ accumulation by plants (Jorgensen, 1993). EDTA was particularly effective in facilitating the phytoextraction by plants of $\mathrm{Cd}, \mathrm{Cu}, \mathrm{Ni}, \mathrm{Pb}$ and $\mathrm{Zn}$. EDTA acts by complexing soluble metals present in soil solution. In view of such diverse reports, an attempt was made to understand the plant-nutrient-chelate interaction in order to examine the heavy metal uptake.

The present study was conducted using phytoextraction to explore the accumulation and removal potential of the heavy metal $\mathrm{Zn}$ by an invasive weed species P.hysterophorus L. belonging to the family Asteraceae wildly grown over large areas in Visakhapatnam city. Zn though a micronutrient, is known to be toxic at higher concentrations (Agarwal et al., 1977; Bradshaw, 1952; Chapman et al., 1939; Goldbold et al., 1983; Hagemeyer et al., 1993). The test species is one of the most popular and dominant indigenous weed species which is well adopted to the polluted environment as affected by the various activities which can accumulate significant amounts of heavy metals. Initially a preliminary study was carried out to screen the uptake efficiency and accumulation potential of $\mathrm{Zn}$ by this species. The uptake was found to be in the range $36.1-414 \mu \mathrm{g} / \mathrm{g}$ in shoots and $17-417.2 \mu \mathrm{g} / \mathrm{g}$ in roots. Basing on these results pot studies were carried out for this species with amendments of different concentrations of $\mathrm{Zn}$. 
The experiment described in this paper was designed in part to assess measurements of total andavailable metal content of $\mathrm{Zn}$ in soil as predictor of metal uptake by an experimental plant. Soil $\mathrm{pH}$, conductivity, available N,P,K in soils, N, P, K, Na and Ca in shoots and roots were measured to investigate their possible modifying influences on metal uptake. As a part of this study the effect of a chelating agent EDTA was also examined which was added to the amended soils in the pots after successful growth of the plants. The overall objectives of this work were:

- To identify a metal tolerant species from natural vegetation and assess the phytoextraction potential of the plant.

- to determine concentrations of $\mathrm{Zn}$ in plant biomass and soils to examine the translocation capacity of the plant.

- to investigate the effect of $\mathrm{Zn}$ on plant growth and the plants ability to accumulate and tolerate the metal.

- to analyse N, P, K, Na, Ca and leaf pigments (chl a, chl b and carotenoids) and study their influences on metal uptake.

- comparison of metal and other parameters of soils and plant biomass grown in amended soils treated with EDTA and without EDTA.

- to assess the feasibility to use green plants for phytoextraction of heavy metals.

Information obtained from this study should provide insight for using native plants to remediate metal contaminated sites.

\section{Materials and methods}

\section{Soil samples and pot experiment}

A green house study was carried out in an artificially amended sandy soil (Typic Ustochrepts) with different concentrations of 250(TC1), 500(TC2) and 1000(TC3) $\mathrm{mg} / \mathrm{kg} \mathrm{Zn} \mathrm{SO} \mathrm{SO}_{4} 7 \mathrm{H}_{2} \mathrm{O}$ with control. Some selected soil characteristics are as follows: $\mathrm{pH}(1: 2) 8.02$ in deionised water; EC $0.116 \mathrm{~ms}$; organic carbon $0.41 \%$; calcium carbonate $1.50 \%$ and $10.9 \mathrm{mg} / \mathrm{kg}$ of extractable $\mathrm{Zn}$.

Pot culture experiments were conducted in botany farmhouse using soil treated (spiked) with zinc sulphate salt and for comparison an unamended (control). The salt was uniformly mixed with air-dried soil filled in pots (6kg soil) and left for stabilization for 2 days. Soil in farmhouse was used for the experiments. One week old seedlings of the weed species P.hysterophorus wildly grown in the farmhouse were procured and 5 plants were transplanted in each pot; out of which only 3 were allowed to grow at a uniform distance after their survival was confirmed. Another two sets of pots of each treatment were maintained for EDTA application. EDTA $(0.1 \mathrm{~g} / \mathrm{kg}$ soil as disodium salt $)$ in solution form was added at pre-flowering stage (20 days from the day of survival) to examine the EDTA effect on metal uptake. Three replicas of each treatment were considered and care was taken to protect from rainwater leaching. Plants were grown under natural light and ambient temperature in order to keep all plants under conditions as similar as possible. Plants were watered with limited amount of well water in the farm at regular intervals. Artificial fertilizers or soil amendments were not added to enhance growth or metal uptake during the course of experiment. 


\section{Plant growth and harvesting}

For growth studies individual plants were grown under similar conditions and 9 plants for each concentration were harvested at a time interval of pre-flowering (20 days), flowering (40 days) and post flowering (60 days) from 3 replicate pots, without damaging the roots. EDTA treated pots were harvested at an interval of one week (Iscoring) and two weeks (II-scoring) from the day of addition.

Maximum recoverable portion of roots were procured and plants were rinsed in distilled water to remove dust and soil mineral particles. The plants were taken to the laboratory, washed with deionised distilled water, separated into root and shoot (including stem, leaves, fruits and inflorescence) parts, dried in oven at $65{ }^{\circ} \mathrm{C}$ for 72 hours (Xian and Shokohifard, 1989). Shoot and root length $(\mathrm{cm})$ and dry biomass $(\mathrm{g})$ of the plant parts (shoot and root) were taken for each treatment and interval. All calculations of $\mathrm{Zn}$ and extraction were done on dry weight basis excepting for leaf pigments where fresh weight was taken into considered.

\section{Analysis of plant mass}

Metal uptake is also depicted as Bioconcentration Factor (BFC). It provides an index of the ability of the plant to accumulate a particular metal with respect to its concentration in the soil substrate (Zayed et al., 1998). It was determined as the ration of $[\text { Metal }]_{\text {plant }}$ tissue/[Metal $]_{\text {soil }}$. It has limited applications if one wishes to compare uptake of a plant species under different treatments. Since change in BCF is related to the individual plant biomass and soil elemental concentrations, the efficiency of BCF is a better understood when compared between different harvests, plant species or elements.

Translocation Factor (TF) gives the shoot to root $\mathrm{Zn}$ concentration and depicts the ability of the plant to translocate the metal species from roots to shoot at different concentrations. It was determined as the ratio of $[\text { Metal }]_{\text {shoot }} /[\text { Metal }]_{\text {root. The }}$ translocation property describes that the contents of heavy metals accumulated in shoots of a plant should be higher than those in its roots, i.e. TF $>1$ to be considered typical of an accumulator plant (Baker, 1981). The shoot to root ratio of contaminant concentrations in all confirmed hyperaccumulators are $>1$, whereas the ratios are invariably $<1$ in non-accumulators (Raskin and Ensley, 2000).

\section{Chemical analysis of plant biomass}

From the oven-dried ground plant materials $0.5 \mathrm{~g}$ was accurately weighed and transferred into Kjeldahl flask and digested slowly using Mixed Acid Digestion procedure (Stewart et al., 1974) with a mixture of $1 \mathrm{ml}$ of $60 \% \mathrm{HClO}_{4}, 5 \mathrm{ml}$ of Con. $\mathrm{HNO}_{3}$ and $0.5 \mathrm{ml}$ of $\mathrm{H}_{2} \mathrm{SO}_{4}$ on moderate heat and increased later. The digestion was continued for 10-15 minutes after the appearance of white fumes. It was then cooled, diluted with deionised distilled water and filtered using Whatman filter paper No.44 and then made upto $50 \mathrm{ml}$ with deionised distilled water. A blank was prepared in similar manner. This filtrate was analysed for the following:

The nitrate nitrogen in plant material was determined by phenol disulphonic acid method by UV-VS Spectrophotometer (Stewart et al., 1974).The phosphorus was determined by molybdenum blue method by UV-VS Spectrophotometer (Stewart et al., 1974). Potassium was determined by the Flame photometric method (APHA, 1989). Micronutrients $\mathrm{Na}$ and $\mathrm{Ca}$ in plant materials were determined by the Flame photometric method (Stewart et al., 1974). Zn metal in sample solutions was quantified using 
Atomic Absorption Spectrophotometer (Perkin Elmer Precisely AAnalyst 200) (Stewart et al., 1974).

Leaf pigments chlorophyll a, chlorophyll $b$ and carotenoids of the leaves in the test species was measured on all the harvest days. For this purpose the second leaf from the top (expanding leaf) was taken into consideration. $0.5 \mathrm{~g}$ of the fresh material was weighed accurately, ground to a fine pulp using a mortar and pestle with the addition of $80 \%$ acetone, centrifuged and the clear supernatant was transferred to a $50 \mathrm{ml}$ volumetric flask. This process was repeated until the residue turns to colourless and the entire solution was made upto the mark with $80 \%$ acetone to read the values in UV-VS Spectrophotometer (Sharma and Rao, 1985).

\section{Chemical analysis of soils}

The soils were air dried for 72 hours, powdered to pass through a $2 \mathrm{~mm}$ sieve and subjected to physico-chemical analysis. Soil $\mathrm{pH}$ was measured in 1:2 of soil to water ratio, organic matter was determined by Walkley Black Method (Sims and Heckendorn, 1991), nitrate nitrogen in soils was extracted with deionised distilled water in the ratio1:1 (w/v) and determined by phenol disulphonic acid method and phosphorus was extracted with $2.5 \%$ acetic acid in the ratio $1: 1(\mathrm{w} / \mathrm{v})$ and determined by molybdenum blue method in U.V - V.S. Spectrophotometer (Stewart et al., 1974). Potassium was extracted with $1 \mathrm{M}$ neutral ammonium acetate $(\mathrm{pH} 7)$ in the ratio $1: 1(\mathrm{w} / \mathrm{v})$ and determined by the Flame photometric method (APHA, 1989).

Total metal concentration in the soil samples was determined by Mixed Acid Digestion procedure (as followed for plant biomass analysis) and the available metal i.e acetic acid $(2.5 \%$ in 1:1 w/v) extractable metal were determined by Atomic Absorption Spectrophotometer (Stewart et al., 1974).

Metals in sample solutions were quantified using atomic absorption spectrophotometer (AAnalyst 200 Perkin Elmer Precisely Version 5.0).

\section{Statistical analysis}

Mean values and SE of the element content were calculated, and analysis of variance (ANOVA) and Student's t-test were performed to observe differences between samples. The differences were considered to be significant at $\mathrm{p} \leq 0.05$ and highly significant at $\mathrm{p} \leq 0.005$ level of significance.

\section{Results and discussions}

\section{Soil properties, nutrients and metal concentrations}

The $\mathrm{pH}$ including EDTA treatments ranged from 8.6 to 9.16. Conductivity was found to be significantly high in metal exposure TC1, when compared to control, TC2 and TC3 in all the harvest days excepting on day 60 including EDTA treatments. Nitrates showed no significant difference within the test concentrations $(p>0.05)$ and a significant difference was observed between harvest days $(\mathrm{p}<0.05)$ of without EDTA treatment as determined by two-way anova (Table 1). A significant increase was found from 20 to 60 days $(\mathrm{p}<0.05)$ of without EDTA treatment and a significant increase could be reported with EDTA treatment when compared to without its treatment $(p<0.05)$ by student's t-test. This shows the effect of EDTA as a chelate. No significant difference was observed between the scorings of EDTA treatment by student's t-test 
(p>0.05). No particular trend of increase or decrease in values was observed with metal exposure (Table 7, 8).

Table 1. Two-way Anova for nitrates in soil (without EDTA treatment)

\begin{tabular}{c|c|c|c|c|c}
\hline Source & DF & SS & MS & F & P \\
\hline Test concs & 3 & 0.0053842 & 0.0017947 & 1.46 & 0.316 \\
Harvest days & 2 & 0.0249687 & 0.0124843 & 10.17 & 0.012 \\
Error & 6 & 0.0073648 & 0.0012275 & & \\
Total & 11 & 0.0377177 & & & \\
S = 0.03504 & R-Sq $=80.47 \% \quad$ R-Sq $(\operatorname{adj})=64.20 \%$ & \\
\hline
\end{tabular}

Phosphorus results showed no significant difference within the test concentrations and harvest days including EDTA treatments by two-way anova ( $p>0.05)$. No significant difference could be reported between the scorings of EDTA treatment or in between EDTA treatment and without its treatment by student's t-test ( $p>0.05)$. Hence, the phosphates seemed to be unaffected in all soil amendments (Table 7 and 8).

Potassium showed a significant difference within test concentrations $(\mathrm{p}<0.05)$ and a highly significant difference in between the harvest days $(\mathrm{p}<0.005)$ of without EDTA treatment by two-way anova (Table 2). There was a significant increase in results from 20 to 40 days by student's t-test $(\mathrm{p}<0.05)$. A highly significant decrease from 20 to 60 days was observed i.e when there was complete maturity of the plants $(p<0.005)$ as determined by student's t-test. Potassium concentrations have reduced with EDTA treatment when compared to those without its treatment showing a highly significant difference $(\mathrm{p}<0.005)$ as determined by student's t-test (Table 2). No difference was found between the harvests of EDTA by student's t-test $(\mathrm{p}>0.05)$.

Table 2. Two-way Anova for potassium in soils (without EDTA treatment)

\begin{tabular}{c|c|c|c|c|c}
\hline Source & DF & SS & MS & F & P \\
\hline Test concs & 3 & 0.0000147 & 0.0000049 & 11.27 & 0.007 \\
Harvest days & 2 & 0.0000465 & 0.0000232 & 53.23 & 0.000 \\
Error & 6 & 0.0000026 & 0.0000004 & & \\
Total & 11 & 0.0000638 & & & \\
S $=0.0006606$ & R-Sq $=95.90 \% \quad$ R-Sq (adj) $=92.48 \%$ & \\
\hline
\end{tabular}

The available metal concentrations in soils have shown a highly significant increase with increase in test concentrations on all harvest days $(\mathrm{p}<0.005)$ of without EDTA treatment and the increase was significant in EDTA treatments $(\mathrm{p}<0.05)$ by two-way anova (Table 3, 4). A highly significant increase was observed in between the test concentrations and control as well as within the test concentrations on all harvest days ( $p<0.005$ ) excepting between TC 2 and TC 3 on $40^{\text {th }}$ day of without EDTA treatment and II-scoring of EDTA treatment as determined by student's t-test ( $p>0.05$ ) as shown in Figure 1. to 5. These results are in agreement with literature (Samiullah Khan and Nazar Khan, 1983). 
Table 3. Two-way Anova for available Zn in soils(without EDTA treatment)

\begin{tabular}{|c|c|c|c|c|c|}
\hline Source & DF & SS & MS & $\mathbf{F}$ & $\mathbf{P}$ \\
\hline Test concs & 3 & 11446.7 & 3815.58 & 19.44 & 0.002 \\
\hline Harvest days & 2 & 396.4 & 198.20 & 1.01 & 0.419 \\
\hline Error & 6 & 1177.4 & 196.24 & & \\
\hline Total & 11 & 13020.5 & & & \\
\hline$S=14.01$ & $\mathrm{R}-\mathrm{Sq}=90.96 \%$ & $\mathrm{R}-\mathrm{Sq}$ & $=83.42 \%$ & & \\
\hline
\end{tabular}

Table 4. Two-way Anova for available Zn in soil (with EDTA treatment)

\begin{tabular}{|c|c|c|c|c|c|}
\hline Source & DF & SS & MS & $\mathbf{F}$ & $\mathbf{P}$ \\
\hline Test concs & 3 & 9429.99 & 3143.33 & 29.67 & $\overline{0.010}$ \\
\hline Harvest days & 1 & 103.68 & 103.68 & 0.98 & 0.395 \\
\hline Error & 3 & 317.85 & 105.95 & & \\
\hline Total & 7 & 9851.52 & & & \\
\hline$S=10.29$ & $\mathrm{R}-\mathrm{Sq}=96.77 \%$ & $\mathrm{R}-\mathrm{Sq}$ & $=92.47 \%$ & & \\
\hline
\end{tabular}

The total metal concentrations in soils also have shown highly significant increase with increase in test concentrations including EDTA treatments $(\mathrm{p}<0.005)$ and no significant difference was found between harvest days including EDTA treatments ( $\mathrm{p}>0.05$ ) by two-way anova (Table 5,6 ). As determined by student's t-test a highly significant difference was reported inbetween the control and test concentrations and within the test concentrations including EDTA treatments on all harvests $(p<0.005)$.

Table 5. Two-way Anova for total Zn in soils (without EDTA treatment)

\begin{tabular}{|c|c|c|c|c|c|}
\hline Source & DF & SS & MS & $\mathbf{F}$ & $\mathbf{P}$ \\
\hline Test concs & 3 & 48142.7 & 16047.6 & 52.54 & 0.000 \\
\hline Harvest days & 2 & 67.9 & 34.0 & 0.11 & 0.897 \\
\hline Error & 6 & 1832.8 & 305.5 & & \\
\hline Total & 11 & 50043.4 & & & \\
\hline$S=17.48$ & $\mathrm{R}-\mathrm{Sq}=96.34 \%$ & $\mathrm{R}-\mathrm{Sq}$ & $=93.29 \%$ & & \\
\hline
\end{tabular}

Table 6. Two-way Anova for total Zn in soil (with EDTA treatment)

\begin{tabular}{|c|c|c|c|c|c|}
\hline Source & DF & SS & MS & $\mathbf{F}$ & $\mathbf{P}$ \\
\hline Test concs & 3 & 24222.3 & 8074.11 & 126.45 & 0.001 \\
\hline Harvest days & 1 & 44.6 & 44.56 & 0.70 & 0.465 \\
\hline Error & 3 & 191.6 & 63.85 & & \\
\hline Total & 7 & 24458.4 & & & \\
\hline$S=7.991$ & $\mathrm{R}-\mathrm{Sq}=99.22 \%$ & $\mathrm{R}-\mathrm{Sq}$ & $=98.17 \%$ & & \\
\hline
\end{tabular}


Table 7. Physicochemical parameters of soils in different test concentration on different harvest day.

\begin{tabular}{|c|c|c|c|c|c|c|c|}
\hline \multirow{3}{*}{ 㺼 } & 苞 & ગ્ & 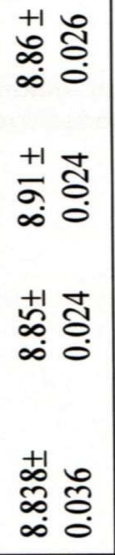 & 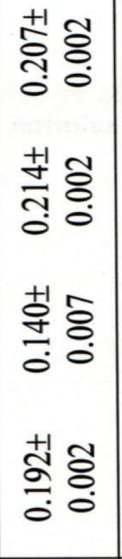 & 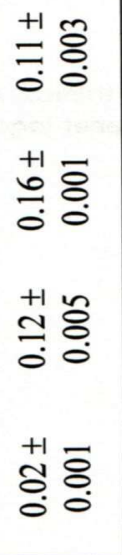 & 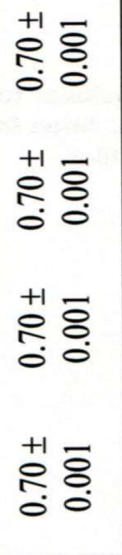 & 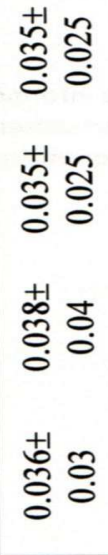 \\
\hline & 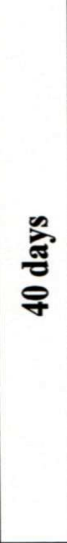 & ర్ & 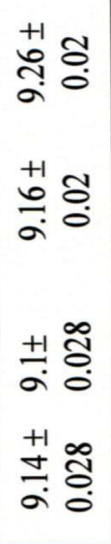 & 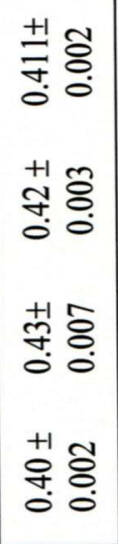 & 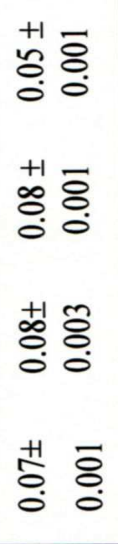 & 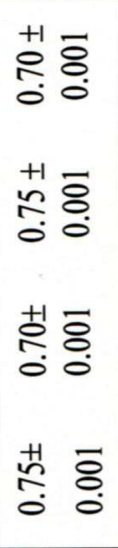 & 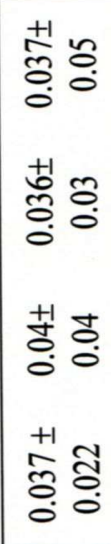 \\
\hline & 突 & $\begin{array}{l}\text { ঠ઼ } \\
\bar{ٍ}\end{array}$ & 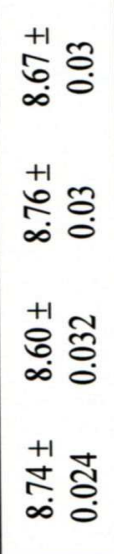 & 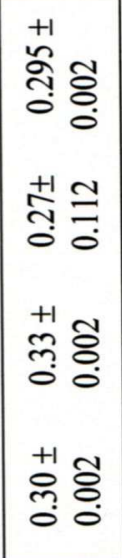 & 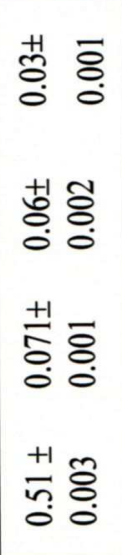 & 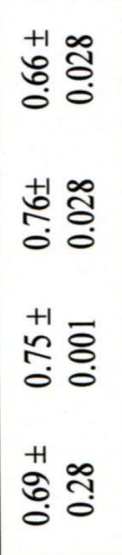 & 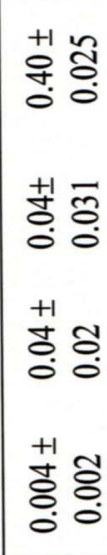 \\
\hline & 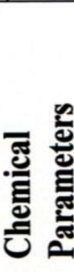 & & 垔 & 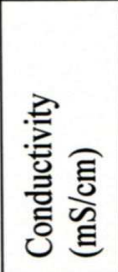 & 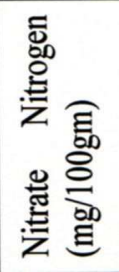 & 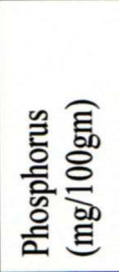 & 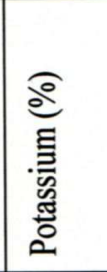 \\
\hline
\end{tabular}

Results are means \pm SE $(n=5)$ 
Table 8. Physicochemical parameters of soils in different test concentration on different harves harvest day

\begin{tabular}{|c|c|c|c|c|c|c|c|c|}
\hline \multicolumn{9}{|c|}{ With EDTA Treatment } \\
\hline \multirow{2}{*}{$\begin{array}{l}\text { Physical \& } \\
\text { Chemical } \\
\text { Parameters }\end{array}$} & \multicolumn{4}{|c|}{ EDTA - I Scoring } & \multicolumn{4}{|c|}{ EDTA - II Scoring } \\
\hline & $\mathbf{C}$ & TC1 & TC2 & TC3 & $\mathbf{C}$ & TC1 & TC2 & TC3 \\
\hline $\mathrm{pH}$ & $\begin{array}{l}9.01 \pm \\
0.024\end{array}$ & $\begin{array}{l}8.84 \pm \\
0.026\end{array}$ & $\begin{array}{r}8.79 \pm \\
0.024\end{array}$ & $\begin{array}{l}8.79 \pm \\
0.026\end{array}$ & $\begin{array}{c}8.92 \pm \\
0.048\end{array}$ & $\begin{array}{l}8.86 \pm \\
0.020\end{array}$ & $\begin{array}{l}8.86 \pm \\
0.024\end{array}$ & $\begin{array}{l}8.79 \pm \\
0.032\end{array}$ \\
\hline $\begin{array}{l}\text { Conductivity } \\
(\mathrm{mS} / \mathrm{cm})\end{array}$ & $\begin{array}{l}0.19 \pm \\
0.004\end{array}$ & $\begin{array}{l}0.25 \pm \\
0.002\end{array}$ & $\begin{array}{c}0.19 \pm \\
0.014\end{array}$ & $\begin{array}{l}0.24 \pm \\
0.004\end{array}$ & $\begin{array}{c}0.17 \pm \\
0.03\end{array}$ & $\begin{array}{l}0.39 \pm \\
0.002\end{array}$ & $\begin{array}{c}0.25 \\
\pm 0.002\end{array}$ & $\begin{array}{l}0.26 \pm \\
0.017\end{array}$ \\
\hline $\begin{array}{l}\text { Nitrate } \\
\text { Nitrogen } \\
\text { (mg/100gm) }\end{array}$ & $\begin{array}{l}0.33 \pm \\
0.003\end{array}$ & $\begin{array}{l}0.25 \pm \\
0.001\end{array}$ & $\begin{array}{l}0.24 \pm \\
0.001\end{array}$ & $\begin{array}{l}0.21 \pm \\
0.001\end{array}$ & $\begin{array}{l}0.06 \pm \\
0.001\end{array}$ & $\begin{array}{l}0.21 \pm \\
0.001\end{array}$ & $\begin{array}{l}0.23 \pm \\
0.001\end{array}$ & $\begin{array}{l}0.24 \pm \\
0.001\end{array}$ \\
\hline $\begin{array}{l}\text { Phosphorus } \\
\text { (mg/100gm) }\end{array}$ & $\begin{array}{l}0.75 \pm \\
0.001\end{array}$ & $\begin{array}{l}0.68 \pm \\
0.034\end{array}$ & $\begin{array}{l}0.75 \pm \\
0.001\end{array}$ & $\begin{array}{l}0.63 \pm \\
0.034\end{array}$ & $\begin{array}{l}0.75 \pm \\
0.001\end{array}$ & $\begin{array}{l}0.60 \pm \\
0.001\end{array}$ & $\begin{array}{l}0.70 \pm \\
0.001\end{array}$ & $\begin{array}{l}0.70 \pm \\
0.001\end{array}$ \\
\hline $\begin{array}{l}\text { Potassium } \\
(\%)\end{array}$ & $\begin{array}{l}0.033 \pm \\
0.042\end{array}$ & $\begin{array}{c}0.037 \pm \\
0.033\end{array}$ & $\begin{array}{c}0.034 \pm \\
0.041\end{array}$ & $\begin{array}{c}0.033 \pm \\
0.02\end{array}$ & $\begin{array}{c}0.032 \pm \\
0.01\end{array}$ & $\begin{array}{l}0.034 \pm \\
0.015\end{array}$ & $\begin{array}{c}0.03 \pm \\
0.02\end{array}$ & $\begin{array}{c}0.035 \\
\pm \\
0.044\end{array}$ \\
\hline
\end{tabular}

Results are means \pm SE $(n=5)$

\section{Zinc uptake, root length, shoot length and plant biomass}

All the analysis and calculations were done on dry weight basis excepting leaf pigments, because dry weight of a tissue can be expected to correlate closely to the nutritional status of the plant, and it depends on the relative rates of photosynthesis and respiration. The fresh weight of a tissue reflects tissue water content and is influenced considerably by the climatic conditions prevailing when the samples are removed.

The shoot and root uptakes have decreased with increase in harvest days and increased with increase in test concentrations in both EDTA and without EDTA treatments $(\mathrm{p}<0.05,0.005)$ by two-way anova (Table 9, 10) which indicates that the efficiency of the plant uptake has reduced with maturity (Ghosh and Singh, 2005). The shoot and root uptakes have shown no significant difference in metal uptake between harvest days of EDTA treatments and also between the EDTA treatment and without its treatment as determined by student's t-test (p>0.05) as shown in Figure 1. to 5.

The shoot and root uptakes have shown a highly significant difference in between the control and test concentrations as well as within the test concentrations including EDTA treatments by student's t-test $(\mathrm{p}<0.005)$ excepting between TC1 and TC2 60th day of without EDTA treatment as shown in Figure 1.1 to 1.5. An increase in uptake with increase in test concentrations was observed and the results were in agreement with literature (Yu-Hong and Youn-Guan 2005). This was an expected trend in accumulation studies. These results indicate that the test species could be a hyperaccumulator. The concentrations of metal uptake by the shoot were high when compared to root uptakes in all the metal exposures on all the harvest days. The results indicate that the test species could be a hyperaccumulator. 
Table 9. Two-way Anova for metal uptake by shoot (without EDTA treatment)

\begin{tabular}{c|c|c|c|c|c}
\hline Source & DF & SS & MS & F & P \\
\hline Test concs & 3 & 18089.1 & 6029.70 & 8.77 & 0.013 \\
Harvest days & 2 & 10139.7 & 5069.83 & 7.37 & 0.024 \\
Error & 6 & 4124.9 & 687.48 & & \\
Total & 11 & 32353.6 & & & \\
\multicolumn{5}{l}{ R-Sq $=87.25 \%$} & R-Sq (adj) $=76.63 \%$ \\
\hline
\end{tabular}

Table 10. Two-way Anova for metal uptake by root (without EDTA treatment)

\begin{tabular}{|c|c|c|c|c|c|}
\hline Source & DF & SS & MS & $\mathbf{F}$ & $\mathbf{P}$ \\
\hline Test concs & 3 & 6125.0 & 2041.67 & 20.67 & 0.001 \\
\hline Harvest days & 2 & 8465.8 & 4232.89 & 42.86 & 0.000 \\
\hline Error & 6 & 592.6 & 98.76 & & \\
\hline Total & 11 & 15183.4 & & & \\
\hline$S=9.938$ & $\mathrm{R}-\mathrm{Sq}=96.10 \%$ & $\mathrm{R}-\mathrm{Sq}$ & $=92.84 \%$ & & \\
\hline
\end{tabular}

The shoot lengths showed a significant difference in between 20 and 40 as well as 20 and 60 harvest days of without EDTA treatment as determined by student's t-test $(p<0.05)$. No significant difference was reported within the test concentrations and also between test concentrations and control on day 40 and 60 as determined by student's ttest ( $p>0.05)$. No significant difference within test concentrations and scorings of EDTA treatment was observed as determined by student's t-test $(\mathrm{p}>0.05)$ indicating that there was no growth. No significant difference could be reported between EDTA treatment and without treatment as determined by student's t-test $(\mathrm{p}>0.05)$ as shown in Figure 6 to 10. Maximum growth was attained in TC3 on day $60(20.06 \mathrm{~cm})$.

The root lengths showed a significant difference between 20 and 40 as well as between 20 and 60 days by student's t-test $(\mathrm{p}<0.05)$. A significant difference was observed in EDTA treated samples when compared to those without its treatment by student's t-test $(\mathrm{p}<0.05)$. No significant difference was reported between 40 to 60 days and the harvests of EDTA treatment $(\mathrm{p}>0.05)$ as determined by student's t-test. No significant difference between the control and test concentrations and within the test concentrations on day 20 could be reported by student's t-test showing no growth $(p>0.05)$. There was no significant difference in between the scorings of EDTA treatment and also between EDTA treatment and without EDTA treatment by student's t-test $(p>0.05)$. A significant increase was found between control and the test concentrations $(\mathrm{p}<0.05)$ and no significant difference within the test concentrations ( $p>0.05$ ) was observed by student's t-test on day 40 as shown in Figure 6. to 10. The overall results of the shoot length and root length indicate that $P$. hysterophorus is tolerant to $\mathrm{Zn}$. 


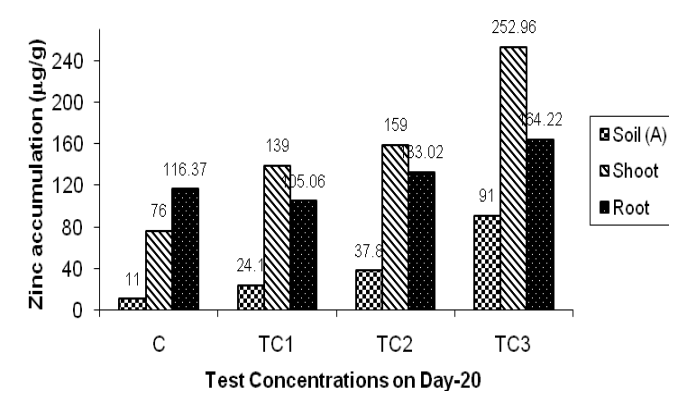

Figure 1. Zinc accumulations of soil, shoot and root in different concentrations on day 20

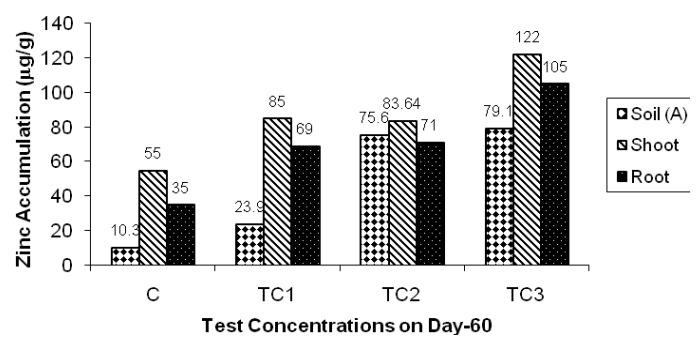

Figure 3. Zinc accumulations of soil, shoot and root in different concentrations on day 60

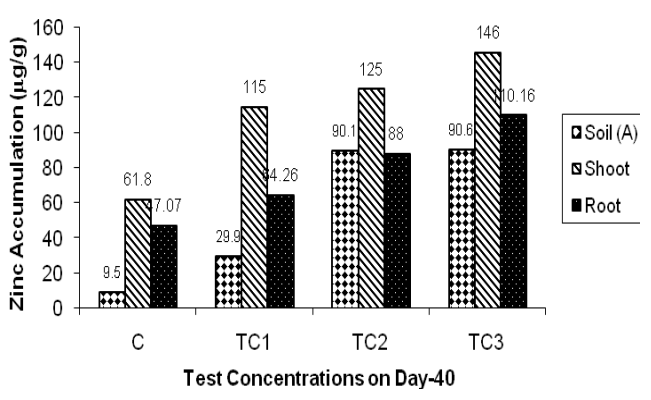

Figure 2. Zinc accumulations of soil, shoot and root in different concentrations on day40

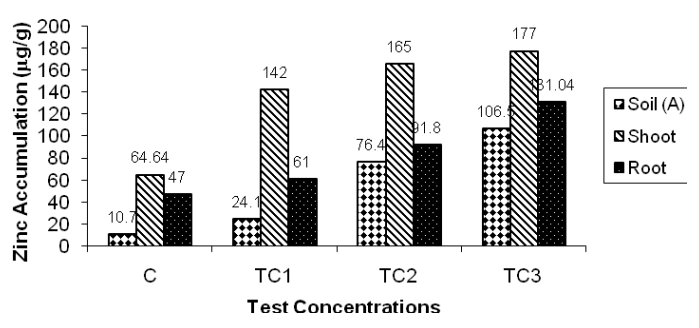

Figure 4. Zinc accumulations of soil, shoot and root in different concentrations on Iscoring of EDTA treatment

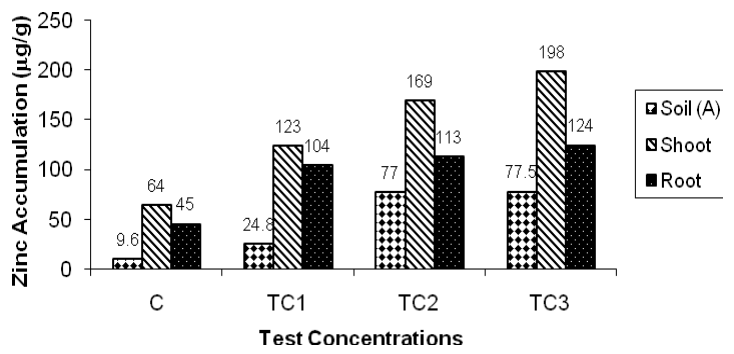

Figure 5. Zinc accumulations of soil, shoot and root in different concentrations on IIscoring of EDTA treatment.

$\mathrm{A}=$ Available metal concentrations in soil 


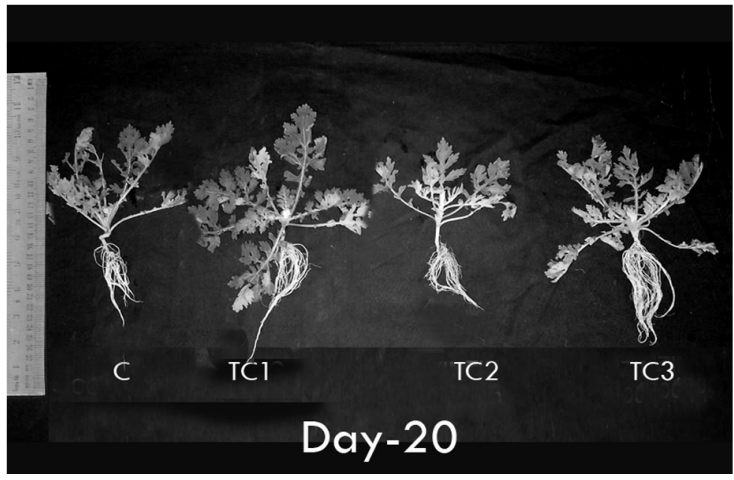

Figure 6. Test species showing variation in different Concentrations on day-20

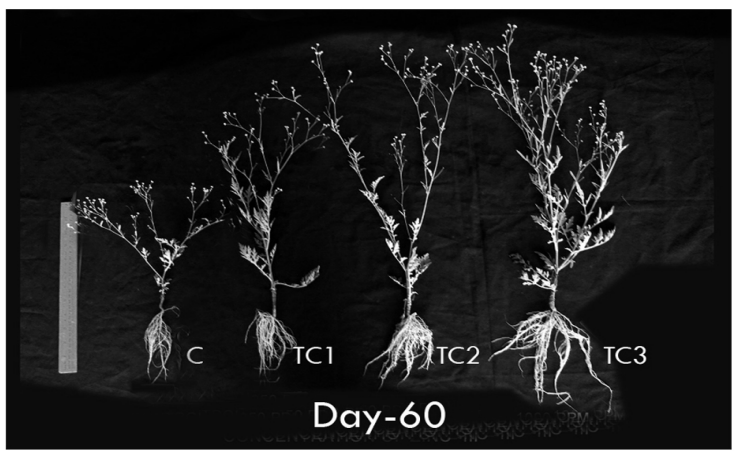

Figure 8. Test species showing variations in different concentrations on day - 60

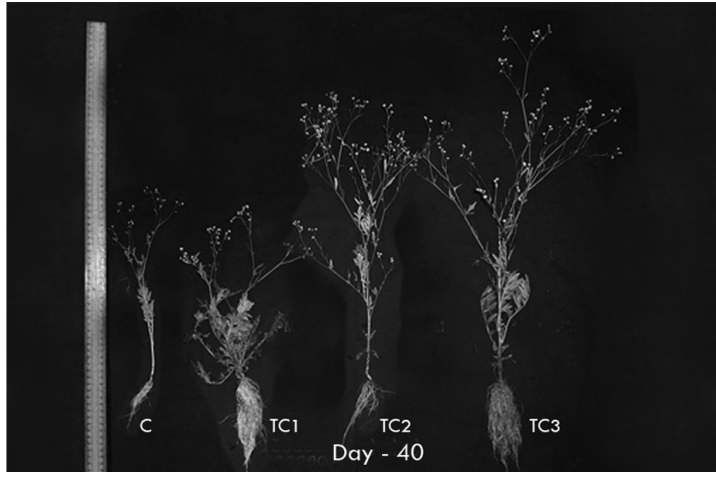

Figure 7. Test species showing variation in different Concentrations on day-40

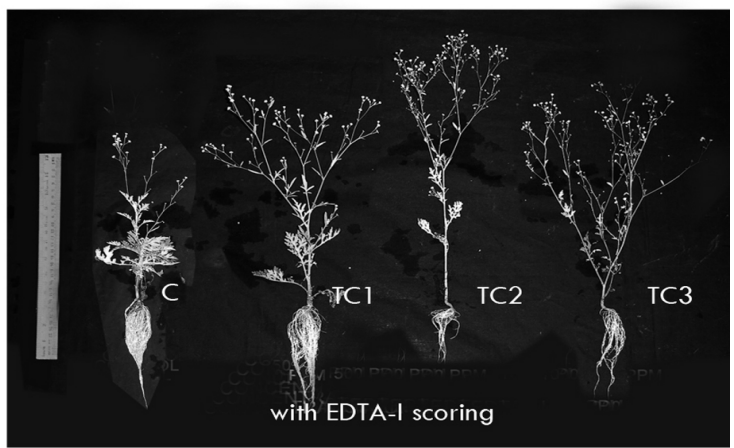

Figure 9. Test species showing variations in different concentrations on I-scoring of EDTA treatment

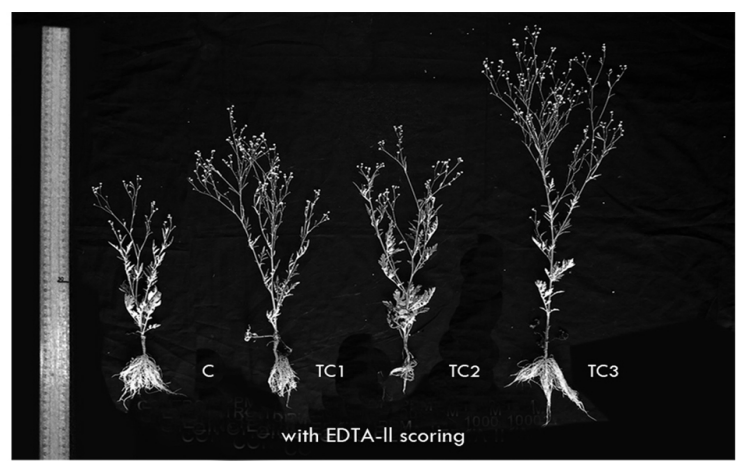

Figure 10. Test species showing variations in different concentrations on II-scoring of EDTA treatment

The pattern of addition of biomass is important for phytoextraction studies to estimate the best time to harvest the biomass, in this case harvesting after 60 days was best, as no mass was added beyond this period.

The shoot biomass (dry matter) showed no significant difference with time including EDTA treatment and between EDTA and without EDTA treatments showing no growth (p>0.05) excepting from 20 to 60 days where the biomass increased showing enough growth as determined by student's t-test $(\mathrm{p}<0.05)$. A significant increase was observed in TC1 when compared to control and decreased in TC2 when compared to TC1 on day 
20 ( $\mathrm{p}<0.05)$. On day 40 also there was increase in shoot biomass of TC1, TC2 and TC3, and on day-60 TC1 and TC2 have increased when compared to control $(\mathrm{p}<0.05)$ by student's t-test. No significant difference was observed within test concentrations on day 60 and EDTA scorings and between test concentrations and control in EDTA scorings by student's t-test $(\mathrm{p}>0.05)$ as shown in Figure 11 to 15 . The maximum amount of shoot biomass was obtained in TC2 on 60th day of without EDTA treatment.

A significant increase was reported in the root biomass (dry matter) from 20 to 60 days of without EDTA treatment $(\mathrm{p}<0.05)$ indicating enough growth and no significant difference was found to be reported in EDTA scorings as well as between EDTA and without EDTA treatments ( $>0.05$ ) by student's t-test as shown in Figure 11. to 15. The increase in root biomass was significantly high $(\mathrm{p}<0.005)$ in all the test concentrations when compared to control on day 40 and on day 60 and a significant increase could be reported only in TC1 and TC2 when compared to control.

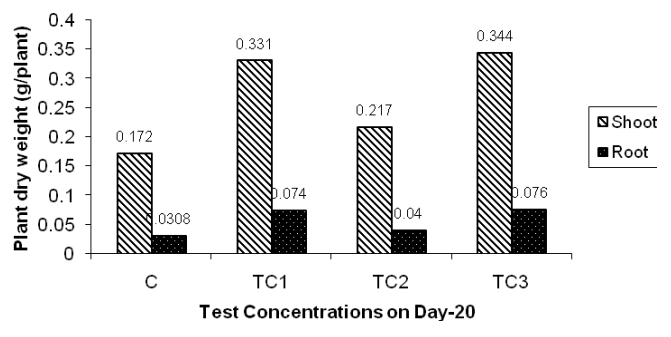

Figure 11. Plant dry wt in different concentrations (g/plant) on day - 20

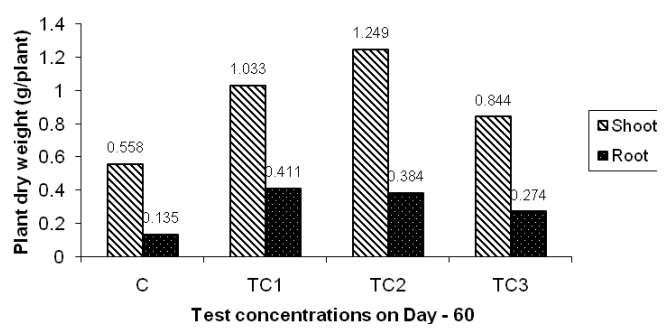

Figure 13. Plant dry wt in different concentrations (g/plant) on day - 60

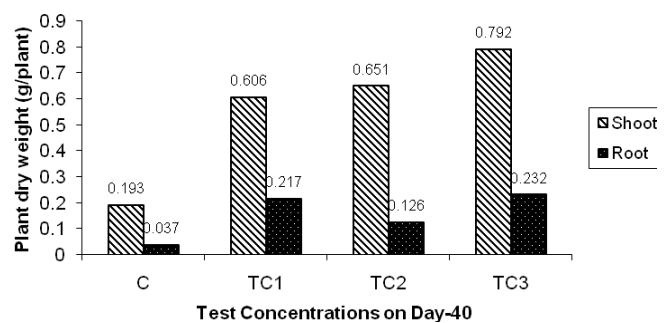

Figure 12. Plant dry wt in different concentrations (g/plant) on day - 40

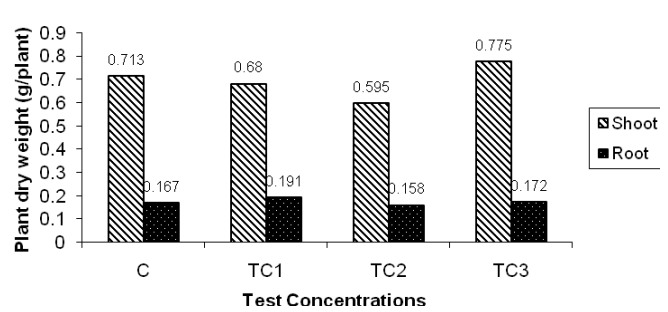

Figure 14. Plant dry wt in different concentrations ( $g /$ plant) on I-scoring of EDTA treatment

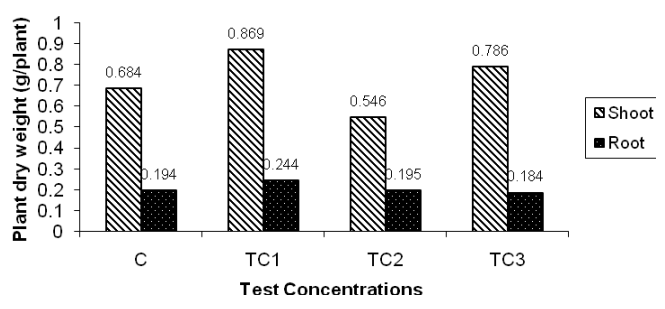

Figure 15. Plant dry wt in different concentrations ( $\mathrm{g} /$ plant) on II-scoring of EDTA treatment 
Maximum amount of root biomass was obtained in TC1 on day-60.Usually, when the concentration of a heavy metal in soils is not higher than the critical value that affects the growth of a plant, the aboveground biomass of a plant will not decrease significantly even though the concentration of the heavy metal in soils is very high. Once when it exceeds the critical value, would the growth of a plant be adversely inhibited, followed by occurrence of abnormal leaf colour, reduction in plant height and decrease in aboveground biomass (Sun et al., 2001; Wei et al., 2004; Zhou et al., 2004).

The results of the plant height and biomass as shown in Figure 6. to 15 suggest that P. hysterophorus L. is tolerant to $\mathrm{Zn}$ typical of a hyperaccumulator (Chaney et al., 1997).

\section{Leaf pigments nutrients and in plants}

Chl 'a' has shown a highly significant decrease in values with time from 20 to 40 days and 20 to 60 days of without EDTA treatment as determined by student's t-test $(\mathrm{p}<0.005)$ and no difference was reported between 40 and 60 days as determined by student's t-test ( $>>0.05)$. The chl ' $a$ ' content in EDTA treatments showed a highly significant reduction when compared to those without its treatment indicating its effect as determined by student's t-test $(\mathrm{p}<0.05)$. A highly significant difference was observed between controls and the test concentrations, within test concentrations on 20,40,60 days of without EDTA treatment and the I-scoring of EDTA treatment as determined by student's t-test $(\mathrm{p}<0.005)$. In the II-scoring of EDTA treatment highly significant difference was reported between controls and test concentrations $(\mathrm{p}<0.005)$ whereas no difference was observed in between within test concentrations $(p>0.05)$ as shown in Figure 16 and 17. The lowest content of chl 'a' was obtained in TC2 on the II-scoring of EDTA treatment. The overall results have shown that metal uptake could effect the chl ' $a$ ' content as it reduced with increase in metal exposures and time.

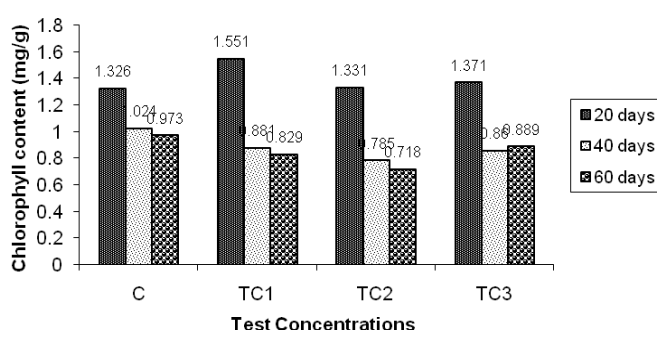

Figure 16. Chlorophyll a content in different concentrations at different harvests $(\mathrm{mg} / \mathrm{g})$

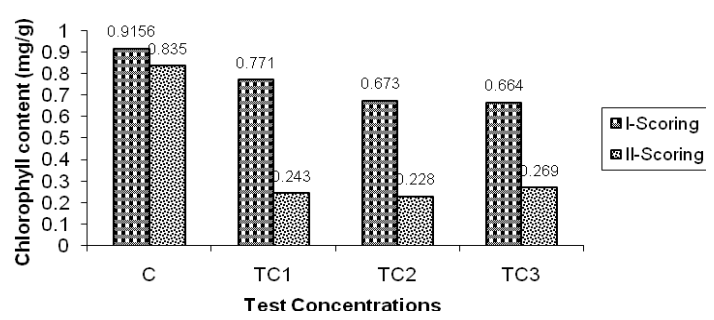

Figure 17. Chlorophyll a content in different concentrations at different harvests $(\mathrm{mg} / \mathrm{g})$ with EDTA treatment

Chl ' $b$ ' has shown highly significantly decrease with increase in time i.e from 20 to 40 and 20 to 60 days $(p<0.005)$ and no significant difference between 40 and 60 days and the scorings of EDTA treatments $(\mathrm{p}>0.05)$ was observed by student's t-test. A significant difference was observed between EDTA and without EDTA treatments as determined by student's t-test $(\mathrm{p}<0.05)$. There was a highly significant difference between control and test concentrations on 40, 60 days and between the test concentrations of EDTA treatment as determined by student's t-test $(p<0.005)$ which is indicative of the metal effect as shown in Figure 18 and 19. The lowest content of chl ' $b$ ' was obtained in TC2 on the II-scoring of EDTA treatment. 


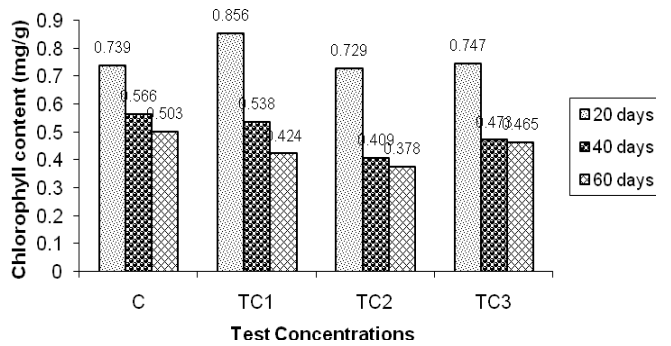

Figure 18. Chlorophyll b content in different concentrations at different harvests $(m g / g)$

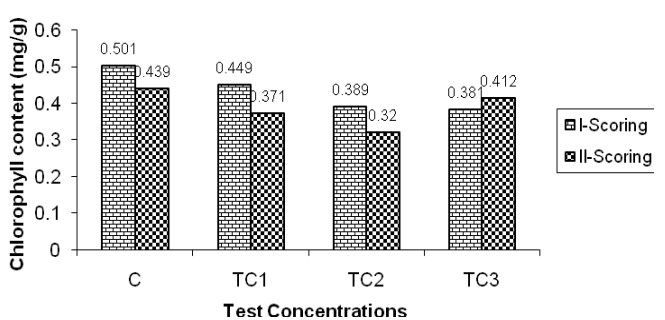

Figure 19. Chlorophyll b content in different concentrations at different harvests $(\mathrm{mg} / \mathrm{g})$ with EDTA treatment

Carotenoids have shown a significant reduction in its values from 20 to 40 days and 20 to 60 days as determined by student's t-test $(\mathrm{p}<0.05)$. A significant difference in EDTA treatment was observed when compared to without its treatment as determined by student's t-test $(\mathrm{p}<0.05)$. There was no difference between 40 and 60 days as well as between EDTA scorings by student's t-test (p>0.05) as shown in Figure 20 and 21. A significant difference was observed between control and test concentrations as well as within the test concentrations on day 40 and 60 days including EDTA $(\mathrm{p}<0.005)$ as determined by student's t-test. The lowest content of carotenoids was obtained in TC2 on II-scoring of EDTA treatment.

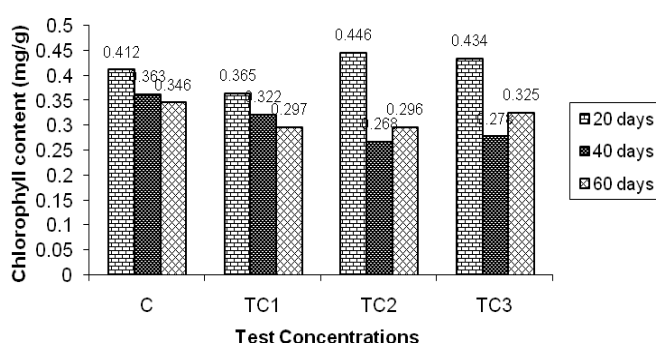

Figure 20. Carotenoids content in different concentrations at different harvests $(\mathrm{mg} / \mathrm{g})$

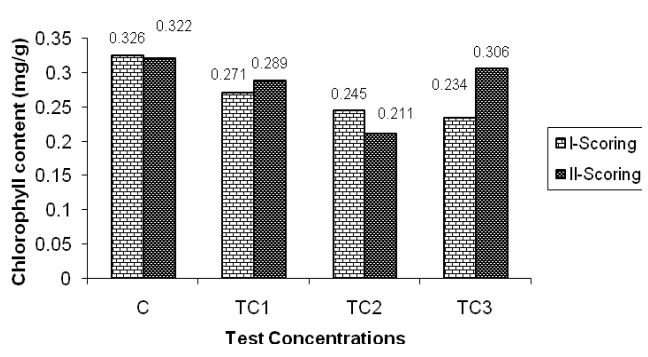

Figure 21. Carotenoids content in different concentrations at different harvests $(\mathrm{mg} / \mathrm{g}$ ) with EDTA treatment

The yellowish colour of the leaves and the reduction in leaf pigments as shown in Figure 16 to 21 are indication of $\mathrm{Zn}$ accumulation which has caused chlorophyll degradation (Prasad and Strzalka, 1999).

The shoot and root nitrates showed no significant difference within the metal exposures and the harvest days including EDTA treatment as determined by two way anova ( $\mathrm{p}>0.05)$. A student's t-test was also conducted and found a highly significant increase in EDTA treatment of shoot when compared to without its treatment $(\mathrm{p}<0.005)$ of shoot. This could be due to the effect of EDTA as a chelating agent with respect to shoot.

The results of shoot and root phosphorus showed no significant difference within exposures and harvest days including EDTA treatment by two way anova $(p>0.05)$. The 
shoot and root phosphorus showed no significant difference between individual harvest days ( $p>0.05)$ including EDTA treatment excepting for a significant decrease from 20 to 40 days in root phosphorus $(\mathrm{p}<0.05)$ as determined by student's t-test. Whereas a highly significant increase was observed in shoots and roots of EDTA treatment when compared to those without its treatment $(\mathrm{p}<0.005)$ showing the effect of the chelate (Table 18, 19).

Shoot and root potassium showed no significant difference within test concentrations ( $p>0.05)$ including EDTA treatment but a highly significant difference $(p<0.005)$ was reported between harvest days of without EDTA treatment where no siginificant difference with EDTA treatment ( $p>0.05$ ) was observed by two way anova (Table 11, 12). No significant difference between EDTA and without EDTA treatments and within the scorings of EDTA treatment of both shoot and root $(p>0.05)$ was observed by student's t-test. A significant difference could be reported between all the harvest days in shoots $(\mathrm{p}<0.05)$ and a highly significant reduction from 40 to 60 days and 20 to 60 harvests $(\mathrm{p}<0.005)$ in roots by student's t-test $($ Table 18, 19). No particular trend of either shoot or root potassium was followed for metal effect.

Table 11. Two-way Anova for potassium in shoot (without EDTA treatment)

\begin{tabular}{|c|c|c|c|c|c|}
\hline Source & DF & SS & MS & $\mathbf{F}$ & $\mathbf{P}$ \\
\hline Test concs & 3 & 0.50117 & 0.16706 & & \\
\hline Harvest days & 2 & 4.99338 & 2.49669 & 1.81 & 0.245 \\
\hline Error & 6 & 0.55282 & 0.09214 & 27.10 & 0.001 \\
\hline Total & 11 & 6.04737 & & & \\
\hline$S=0.3035$ & $\mathrm{R}-\mathrm{Sq}=90.86 \%$ & $\mathrm{R}-\mathrm{Sc}$ & $=83.24 \%$ & & \\
\hline
\end{tabular}

Table 12. Two-way Anova for potassium in root (without EDTA treatment)

\begin{tabular}{|c|c|c|c|c|c|}
\hline Source & DF & SS & MS & $\mathbf{F}$ & $\mathbf{P}$ \\
\hline Test concs & 3 & 0.04776 & 0.015921 & 0.72 & 0.576 \\
\hline Harvest days & 2 & 0.81989 & 0.409943 & 18.51 & 0.003 \\
\hline Error & 6 & 0.13286 & 0.022144 & & \\
\hline Total & 11 & 1.00051 & & & \\
\hline$S=0.1488$ & $\mathrm{R}-\mathrm{Sq}=86.72 \%$ & $\mathrm{R}-\mathrm{Sq}$ & $=75.65 \%$ & & \\
\hline
\end{tabular}

The shoot and root sodium results have shown no significant difference within exposures $(\mathrm{p}>0.05)$ and a significant difference was observed between harvest days ( $<<0.005$ for shoot $\& \mathrm{p}<0.05$ for root) of without EDTA treatment as determined by two-way anova (Table 13, 14). EDTA harvests showed significant difference within test concentrations in shoots and between harvests as well as within test concentrations in roots $(\mathrm{p}<0.05)$ by two way anova $($ Table 15,16$)$. Using student's t-test it was found that sodium in shoots have decreased from 40 to 60 days and 20 to 60 days ( $<<0.05$ and $\mathrm{p}<0.005)$ and in roots from 20 to 60 days $(\mathrm{p}<0.05)$. There was no significant difference between EDTA and without EDTA treatment in shoots $(\mathrm{p}>0.05)$ whereas, an increase in values of EDTA treatment when compared to without its treatment were observed in roots $(\mathrm{p}<0.05)$ by student's t-test. No significant difference could be reported between the scorings of EDTA in either the shoot or root sodium levels ( $>0.05)$ by student's $t$ test (Table 18, 19). 
Table 13. Two-way Anova for sodium in shoot (without EDTA treatment)

\begin{tabular}{c|c|c|c|c|c}
\hline Source & DF & SS & MS & F & P \\
\hline Test concs & 3 & 0.021150 & 0.0070500 & 3.48 & 0.090 \\
Harvest days & 2 & 0.080825 & 0.0404123 & 19.96 & 0.002 \\
Error & 6 & 0.012148 & 0.0020246 & & \\
Total & 11 & 0.114122 & & & \\
S = $0.04500 \quad$ R-Sq $=89.36 \%$ & R-Sq (adj) $=80.49 \%$ \\
\hline
\end{tabular}

Table 14. Two-way Anova for sodium in root (without EDTA treatment)

\begin{tabular}{c|c|c|c|c|c}
\hline Source & DF & SS & MS & F & P \\
\hline Test concs & 3 & 0.0049753 & 0.0016584 & 1.83 & 0.242 \\
Harvest days & 2 & 0.0169965 & 0.0084983 & 9.38 & 0.014 \\
Error & 6 & 0.0054385 & 0.0009064 & & \\
Total & 11 & 0.0274103 & & & \\
S $=0.03011 \quad$ R-Sq $=80.16 \% \quad$ R-Sq (adj) $=63.62 \%$ \\
\hline
\end{tabular}

Table 15. Two-way Anova for sodium in shoot with EDTA treatment

\begin{tabular}{c|c|c|c|c|c}
\hline Source & DF & SS & MS & F & P \\
\hline Test concs & 3 & 0.028576 & 0.0095253 & 9.36 & 0.049 \\
Harvest days & 1 & 0.001800 & 0.0018000 & 1.77 & 0.276 \\
Error & 3 & 0.003052 & 0.0010173 & & \\
Total & 7 & 0.033428 & & & \\
S $=0.3190 \quad$ R-Sq $=90.87 \%$ & R-Sq (adj) $=75.65 \%$ \\
\hline
\end{tabular}

Table 16. Two-way Anova for sodium in root with EDTA treatment

\begin{tabular}{c|c|c|c|c|c}
\hline Source & DF & SS & MS & F & P \\
\hline Test concs & 3 & 0.0158954 & 0.0152985 & 22.72 & 0.015 \\
Harvest days & 1 & 0.0128801 & 0.0128801 & 19.13 & 0.022 \\
Error & 3 & 0.0020204 & 0.0006735 & & \\
Total & 71 & 0.0607959 & & & \\
S $=0.2595 \quad$ R-Sq $=96.68 \%$ & R-Sq (adj) $=92.25 \%$ \\
\hline
\end{tabular}

Shoot and root calcium showed no significant difference within exposures and between harvests including EDTA treatments by two way anova ( $p>0.05)$ excepting between harvests of shoots of without EDTA treatment (Table 17). A highly significant increase in shoot of EDTA treatment when compared to without its treatment was observed by student's t-test $(\mathrm{p}<0.005)$ showing its effect as a chelate. From student's ttest both shoot and root showed no significant difference $(p>0.05)$ between harvests of EDTA and without EDTA could be reported (Table 18, 19). 
Table 17. Two-way Anova for calcium in shoo t(without EDTA treatment)

\begin{tabular}{c|c|c|c|c|c}
\hline Source & DF & SS & MS & F & P \\
\hline Test concs & 3 & 0.0280477 & 0.0093492 & 4.54 & 0.055 \\
Harvest days & 2 & 0.0283954 & 0.0141977 & 6.89 & 0.028 \\
Error & 6 & 0.0123585 & 0.0020597 & & \\
Total & 11 & 0.0688016 & & & \\
S = $0.4538 \quad$ R-Sq $=82.04 \%$ & R-Sq (adj) $=67.07 \%$ \\
\hline
\end{tabular}

\section{Bioconcentration and translocation factors}

The BCF of shoot has decreased with time (harvests), this means the power of $\mathrm{Zn}$ accumulation reduced with maturity of the plant. It is bound to get reduced in soils and the same trend was observed in shoot and root and also in EDTA treatment of shoot. Whereas the BCF of root has increased with time in EDTA treatment showing that the plant is extracting more metal and was in agreement with earlier studies (Ghosh and Singh, 2005). The BCF being greater $>1$ indicates that P.hysterophorus is efficient in bioconcentrating zinc into shoots and roots though the roots showed lower efficiency.

Plants must have the ability to translocate $\mathrm{Zn}$ from root to shoot or compartmentalize it in order to continue absorption of $\mathrm{Zn}$ from the substrate. Better translocation is advantageous for uptake (Ghosh and Singh, 2005). Translocation to shoot is one of the mechanisms of resistence to high $\mathrm{Zn}$ levels. The TF of without EDTA treatment has increased from the first (20 days) to the second (40 days) harvest and reduced on the third (60 days) harvest i.e decreased on complete maturity. The TF has decreased with increase in metal exposures in the I-scoring of EDTA and in the II-scoring of EDTA there was a slight decrease from TC1 to TC2 and then a slight increase from TC2 to TC3. The overall results showed that the TF $>1$ which is an indication of the test species efficiency in uptake and translocation of $\mathrm{Zn}$ and can be considered as a hyperaccumulator (Baker, 1981). The shoot to root ratio of contaminant concentrations in all confirmed hyperaccumulators are $>1$, whereas the ratios are invariably $<1$ in nonaccumulators (Raskin and Ensley, 2000). 
Table 18. Nutrients of Shoot and Root in different test concentration on different harvest days

\begin{tabular}{|c|c|c|c|c|c|c|c|c|}
\hline & ల̂t & 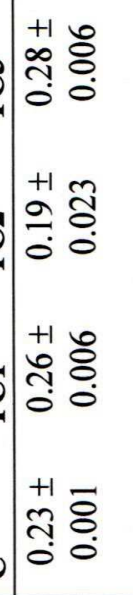 & 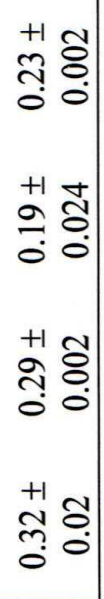 & 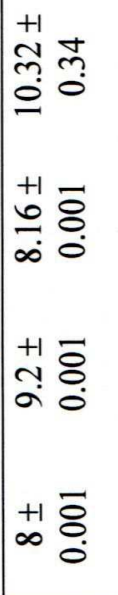 & 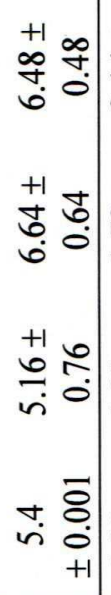 & 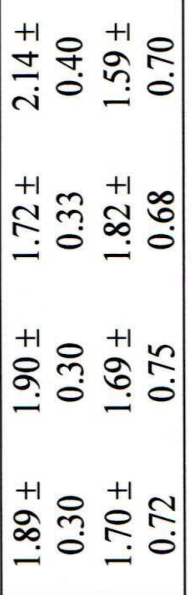 & 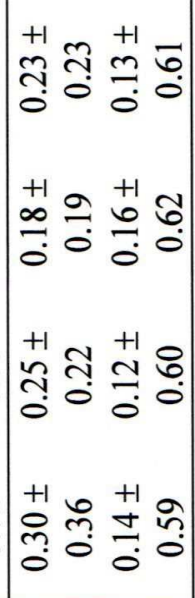 & 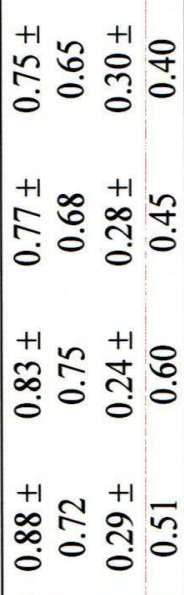 \\
\hline 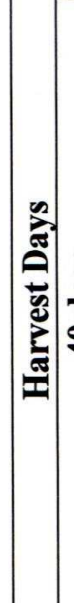 & 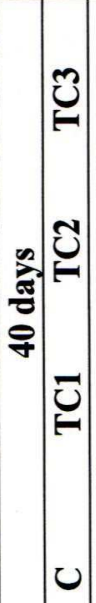 & 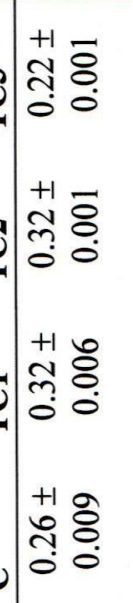 & 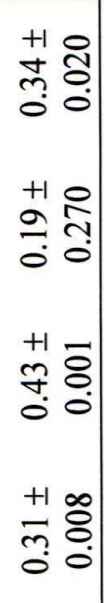 & 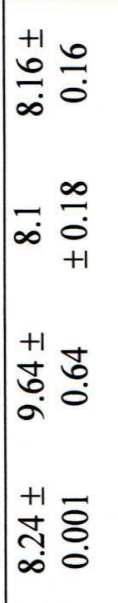 & 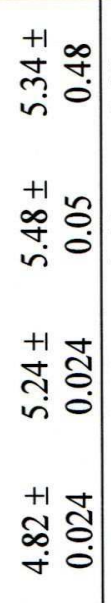 & 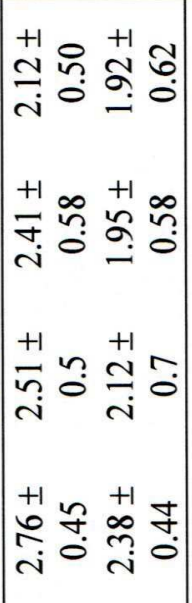 & 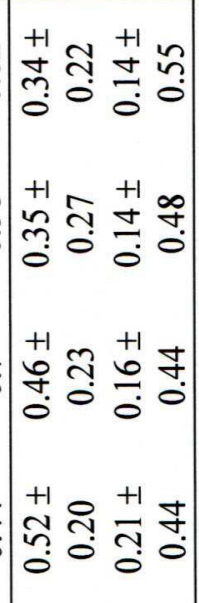 & 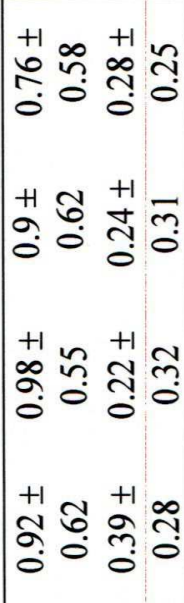 \\
\hline & 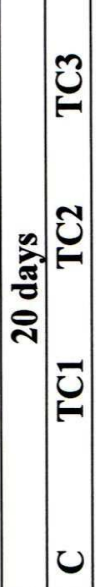 & 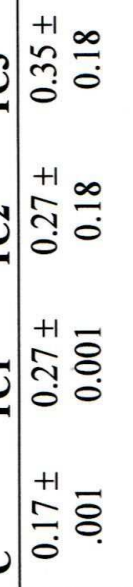 & 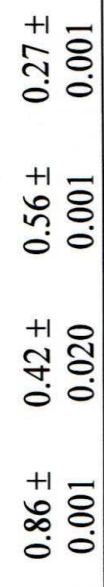 & 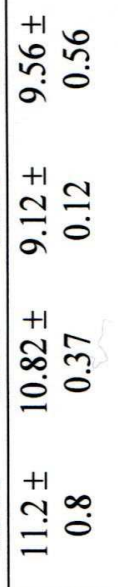 & 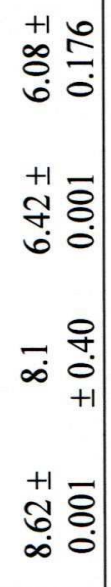 & 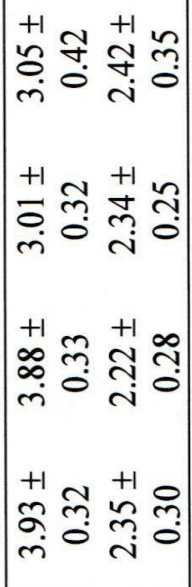 & 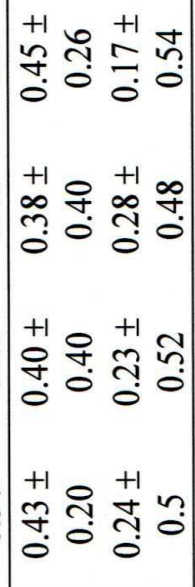 & 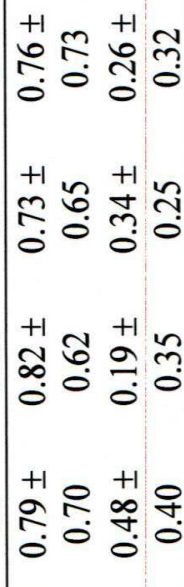 \\
\hline لَّ & & 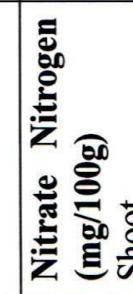 & & 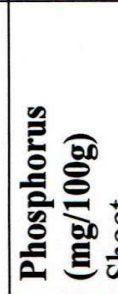 & & 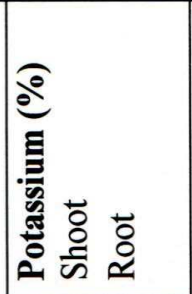 & 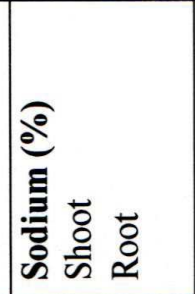 & 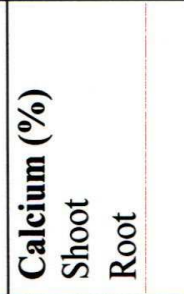 \\
\hline
\end{tabular}

Results are means \pm SE $(n=5)$ 
Table 19. Nutrients of Shoot and Root in different test concentration on different harvest days

\begin{tabular}{|c|c|c|c|c|c|c|c|c|}
\hline \multirow{3}{*}{ Parameter } & \multirow[b]{3}{*}{ C } & \multicolumn{7}{|c|}{ With EDTA Treatment } \\
\hline & & \multicolumn{3}{|c|}{ EDTA - I Scoring } & \multicolumn{4}{|c|}{ EDTA - II Scoring } \\
\hline & & TC1 & TC2 & TC3 & $\mathbf{C}$ & TC1 & TC2 & TC3 \\
\hline $\begin{array}{l}\text { Nitrate Nitrogen } \\
\text { (mg/100g) }\end{array}$ & $\begin{array}{l}0.40 \pm \\
0.006\end{array}$ & & $\begin{array}{c}0.27 \pm \\
0.14\end{array}$ & & $\begin{array}{l}0.30 \pm \\
0.006\end{array}$ & & $\begin{array}{l}0.5 \pm \\
0.001\end{array}$ & $\begin{array}{l}0.5 \pm \\
0.001\end{array}$ \\
\hline $\begin{array}{l}\text { Shoot } \\
\text { Root }\end{array}$ & $\begin{array}{c}0.26 \pm \\
0.006\end{array}$ & $\begin{array}{c}0.39 \pm \\
0.002\end{array}$ & $\begin{array}{c}0.30 \pm \\
0.013\end{array}$ & $\begin{array}{l}0.30 \pm \\
0.006\end{array}$ & $\begin{array}{c}0.70 \pm \\
0.14\end{array}$ & & $\begin{array}{c}0.37 \pm \\
0.001\end{array}$ & $\begin{array}{l}0.37 \pm \\
0.012\end{array}$ \\
\hline & & $\begin{array}{r}13.16 \\
\pm 0.16\end{array}$ & $\begin{array}{c}16.74 \\
\pm 0.24\end{array}$ & $\begin{array}{c}14.74 \\
\pm 0.24\end{array}$ & $\begin{array}{c}11.48 \\
\pm 0.48\end{array}$ & & & $\begin{array}{c}20 \pm \\
0.001\end{array}$ \\
\hline $\begin{array}{l}\text { Shoot } \\
\text { Root }\end{array}$ & $\begin{array}{c}5.9 \pm \\
0.4\end{array}$ & $\begin{array}{c}8 \pm \\
0.001\end{array}$ & $\begin{array}{c}9.79 \pm \\
0.001\end{array}$ & $\begin{array}{l}7.9 \pm \\
0.001\end{array}$ & $\begin{array}{c}7.16 \pm \\
0.76\end{array}$ & $\begin{array}{c}9.16 \pm \\
0.16\end{array}$ & $\begin{array}{c}9.64 \pm \\
0.64\end{array}$ & $\begin{array}{c}11.2 \pm \\
0.001\end{array}$ \\
\hline Potassium (\%) & $\begin{array}{c}2.30 \pm \\
0.4\end{array}$ & $\begin{array}{c}2.44 \pm \\
0.48\end{array}$ & $\begin{array}{c}2.53 \pm \\
0.6\end{array}$ & $\begin{array}{c}2.58 \pm \\
0.52\end{array}$ & $\begin{array}{c}1.20 \pm \\
0.54\end{array}$ & $\begin{array}{c}2.15 \pm \\
0.61\end{array}$ & $\begin{array}{c}2.44 \pm \\
0.45\end{array}$ & $\begin{array}{l}2.7 \pm \\
0.53\end{array}$ \\
\hline $\begin{array}{l}\text { Shoot } \\
\text { Root }\end{array}$ & $\begin{array}{c}1.91 \pm \\
0.22\end{array}$ & $\begin{array}{c}2.03 \pm \\
0.27\end{array}$ & $\begin{array}{c}2.08 \pm \\
0.3\end{array}$ & $\begin{array}{c}1.97 \pm \\
0.3\end{array}$ & $\begin{array}{c}2.02 \pm \\
0.38\end{array}$ & $\begin{array}{c}2.04 \pm \\
0.3\end{array}$ & $\begin{array}{c}2.4 \pm \\
0.4\end{array}$ & $\begin{array}{c}2.16 \pm \\
0.43\end{array}$ \\
\hline Sodium (\%) & $\begin{array}{c}0.34 \pm \\
0.18\end{array}$ & $\begin{array}{c}0.46 \pm \\
0.2\end{array}$ & $\begin{array}{c}0.46 \pm \\
0.22\end{array}$ & $\begin{array}{c}0.36 \pm \\
0.28\end{array}$ & $\begin{array}{c}0.26 \pm \\
0.32\end{array}$ & $\begin{array}{c}0.43 \pm \\
0.38\end{array}$ & $\begin{array}{c}0.44 \pm \\
0.4\end{array}$ & $\begin{array}{c}0.38 \pm \\
0.35\end{array}$ \\
\hline $\begin{array}{l}\text { Shoot } \\
\text { Root }\end{array}$ & $\begin{array}{c}0.12 \pm \\
0.60\end{array}$ & $\begin{array}{c}0.26 \pm \\
0.55\end{array}$ & $\begin{array}{c}0.28 \pm \\
0.49\end{array}$ & $\begin{array}{c}0.25 \pm \\
0.51\end{array}$ & $\begin{array}{c}0.15 \pm \\
0.47\end{array}$ & $\begin{array}{l}0.37 \pm \\
0.45\end{array}$ & $\begin{array}{c}0.36 \pm \\
0.43\end{array}$ & $\begin{array}{c}0.36 \pm \\
0.39\end{array}$ \\
\hline Calcium (\%) & $\begin{array}{c}1.04 \pm \\
0.69\end{array}$ & $\begin{array}{c}1.00 \pm \\
0.60\end{array}$ & $\begin{array}{c}0.96 \pm \\
0.52\end{array}$ & $\begin{array}{c}0.82 \pm \\
0.48\end{array}$ & $\begin{array}{c}0.98 \pm \\
0.42\end{array}$ & $\begin{array}{c}0.86 \pm \\
0.55\end{array}$ & $\begin{array}{c}0.96 \pm \\
0.48\end{array}$ & $\begin{array}{c}1.03 \pm \\
0.55\end{array}$ \\
\hline $\begin{array}{l}\text { Shoot } \\
\text { Root }\end{array}$ & $\begin{array}{c}0.24 \pm \\
0.51\end{array}$ & $\begin{array}{c}0.22 \pm \\
0.35\end{array}$ & $\begin{array}{c}0.22 \pm \\
0.40\end{array}$ & $\begin{array}{c}0.19 \pm \\
0.45\end{array}$ & $\begin{array}{c}0.23 \pm \\
0.5\end{array}$ & $\begin{array}{c}0.25 \pm \\
0.58 \\
\end{array}$ & $\begin{array}{c}0.31 \pm \\
0.70\end{array}$ & $\begin{array}{c}0.31 \pm \\
0.75 \\
\end{array}$ \\
\hline
\end{tabular}

Results are means \pm SE $(n=5)$

\section{Conclusions}

A significant increase in shoot and root concentrations of the heavy metal $\mathrm{Zn}$ with increase in test concentrations in the medium shows a positive response of the P.hyterophorus for its accumulation (Wei, 2004). The plant tolerance for $\mathrm{Zn}$ was evident in form of increase in plant height and total biomass of the plant. The plants in all the concentrations grew till maturity. An increase in plant height and plant biomass with respect to time was positive. There was an increase in uptake with increase in test concentrations which is in agreement with earlier studies (Yu-Hong and Youn-Guan, 2005). The highest uptake was observed in TC3 on day 20 in both shoot and root $(252.96 \mu \mathrm{g} / \mathrm{g} \& 164.22 \mu \mathrm{g} / \mathrm{g})$. In EDTA treatment also the highest uptake was observed in TC3 for both shoot and root on both the scorings $(177 \mu \mathrm{g} / \mathrm{g}, 131.04 \mu \mathrm{g} / \mathrm{g}$ on I-scoring \& $198 \mu \mathrm{g} / \mathrm{g} \& 124 \mu \mathrm{g} / \mathrm{g}$ on II-scoring).

The BCF of shoot has decreased with time indicating that $\mathrm{Zn}$ accumulation reduced with maturity of the plant. Whereas the BCF of root has increased with time in EDTA treatment showing that the plant is extracting more metal and metal enhancement due to EDTA treatment. The increase in BCF with time was in agreement with literature (Ghosh and Singh, 2005). The translocation property described that the content of heavy metals accumulated in shoot (including stems and leaves) of a plant should be higher than those in its roots, i.e TF $>1$. On the basis of our work, endurance property and enrichment factor property should be considered as judging standards of hyperaccumulators too (Ma et al., 2001; Wei and Zhou, 2004; Zhou and Song, 2004). 
The enduring characteristic means that hyperaccumulators should have strong endurance to heavy metals contamination. For plants tested under experimental conditions, the aboveground biomass (the sum of dry stems, leaves and inflorescence) of hyperaccumulators should not significantly be decreased compared with the control when they are growing in soils contaminated by heavy metals seriously. At least the aboveground biomasses of plants should not be significantly reduced when the levels in soils are high enough to make the contents of heavy metals absorbed by plants reaching the critical concentration standards what hyperaccumulators should accumulate. Enrichment factor characteristic should be $>1$, and at least the EF should be higher than 1 when the content of a heavy metal in soil is roughly equal to the minimum of a hyperaccumulator. According to these standards, P. hysterophorus can be validated as a hyperaccumulator, because the plant displayed strong tolerance to and translocation ability of $\mathrm{Zn}$ and EF in shoots was $>1$. The concentration of $\mathrm{Zn}$ accumulated by the test species was increased significantly after $0.1 \mathrm{~g} / \mathrm{kg}$ of EDTA was added to the medium. This was in agreement with the findings in literature (Turgut et al., 2004). Phosphorus is one of the chemical constituent of the soil which interferes with zinc uptake by plants (Lindsay, 1972). The uptake will be high in low phosphorus soils. A similar trend was observed in the present study. Shoot and root potassium have decreased with decrease in metal uptake and increase in time including EDTA treatment. The sodium levels in shoot and root of without EDTA treatment decreased with drecrease in metal uptake and increase in time, root sodium of EDTA treatment decreased with increase in metal uptake and increase time. The plant potassium and sodium (without EDTA treatment) were directly proportional to the metal uptake. Shoot nitrates and calcium, root sodium, shoot and root phosphorus have shown significant increase with EDTA treatment showing the effect of EDTA in enhancement of nutrient uptake. Shoot calcium without EDTA treatment increased with growth and slightly reduced at complete maturity. The overall results have shown that the metal uptake could effect the chl a, b and carotenoids content as it reduced with increase in metal exposures and time and especially in edta treatment. This could possibly be due to the accumulation of the $\mathrm{Zn}$. It has been reported that heavy metals are accumulated in the plants maximally and cause chlorophyll degradation due to heavy metal stress (Prasad and Strzalka, 1999).The accumulator species such as Brassica species and other accumulator crop species required special care in field applications. Whereas weeds such as P.hysterophorus in the present study required no care to grow, this is a practical problem that will require care in filed applications. The BCFs of shoots and roots and TFs being $>1$ showing its validity for hyperaccumualtion of the metal can be a promising species for phytoextraction of heavy metals and remediation of metal contaminated soils.

Acknowledgements. We gratefully acknowledge the cooperation and facilities provided by Department of Environmental Sciences, Andhra University, Visakhapatnam.

\section{REFERENCES}

[1] Agarwal, S.C., Bischt, S.S., Sharma, C. (1977): Relative effectiveness of certain heavy metals in producing toxicity and symptoms of iron deficiency in barley. - Canadian Journal of Botany 55: 1299-1307.

[2] Alloway, B.J. (1990): In Heavy metals in soils. - John Wiley and Sons Incorporation, New York. 
[3] APHA (1989): Standard methods for the examination of water and waste waters. $-17^{\text {th }}$ ed., Washington, DC pp.1000-4500.

[4] Baker, A.J.M. (1981): Accumulators and excluders - strategies in the responseof plants to heavy metals. - Journal of Plant Nutrition 3: 643-654.

[5] Baker, A.J.M., McGrath, S.P., Sidoli, C.M.D., Reeves, R.D. (1994): The possibility of in situ heavy metals decontamination of polluted soils using crops of metal-accumulating plants. - Resources Conservation and Recycling 11: 41-49.

[6] Bennet, L.E., Burkhead, J.L., Hale, K.L., Terry, N., Pilon, M., Pilon-Smits, E.A.H. (2003): Analysis of transgenic Indian mustard plants for Phytoremediation of metal contaminated mine tailings. - Journal of Environironmental Quality 32(2): 432-440.

[7] Bradshaw, A.D. (1952): Population of Agrostic tenuic resistant to lead and zinc poisoning nature. - London, 169: 1098.

[8] Chaney, R.L., Malik, M., Li, Y.M. (1997): Phytoremediation of soil metals. - Current Opinion in Biotechnology 8: 279-284.

[9] Chapman, H.D., Liebig, G.F. Jr., Vanselow, A.P. (1939): Some nutritional relationships are revealed by a study of mineral deficiency and excess symptoms on citrus. - Soil Science Soceity of American Proceedings 4: 196-200.

[10] Comis, D. (1996): Green Remediation. - Journal Soil and Water Conservation. 51: 184187.

[11] Cunningham, S.D, Berti, W.R., Huang, J.W. (1995): Phytoremediation of contaminated soils. - Trends in Biotechnology 13: 393-397.

[12] Dudka, S., Piotrowska, M., Terelak, H. (1996): Transfer of cadmium, lead and zinc from industrially contaminated soil to crop plants: A field study. - Environmental Pollution 94(2): 181-188.

[13] Ghosh, M., Singh, S.P. (2005): Comparative uptake and phytoextraction study of soil induced chromium by accumulator and high biomass weed species. - Applied Ecology and Environmental Research 3(2): 67-79.

[14] Goldbold, D.L., Horst, W.J., Marschner, H., Collins, J.C., Thurman, D.A. (1983): Root growth and zinc uptake by two ecotype of Deschampsia caesoitosa as affected by high zinc concentrations. - Journal of Pflanzenphysiology 112: 315-324.

[15] Hagemeyer, J., Lohrmann, D., Breckle, S.W. (1993): Development of annual xylem rings and shoot growth of young beech (Fague sylvatica L.) grown in soil with various cadmium and zinc levels. - Water, Air and Soil Pollution 69: 351-361.

[16] Hovmand, M.F., Tjell, J.C., Mosback, H. (1983): Plant uptake of air borne cadmium. Environmental Pollution 30: 27-38.

[17] Huchabee, J.W., Sanz Daiaz, F., Janzen, S.A., Solomon, J. (1983): Distribution of mercury in vegetation at Almaden, Spain. - Environmental Pollution 30: 211-224.

[18] John, M.K. (1973): Cadmium uptake by eight food crops as influenced by various soil levels of cadmium. - Enviornmental Pollution 4: 7-15.

[19] John, M.K., Lakerhoven, C.J., Chuah, H.H. (1972): Factors affecting plant uptake and phytotoxicity of cadmium added to soils. - Environmental Science and Technology 6: 1005-1009.

[20] Jorgensen, S.E. (1993): Removal of heavy metal from compost and soil by ecotechnological methods. - Ecological Engineering 2: 89-100.

[21] Jung, M.C., Thornton. I. (1996): Heavy metal contamination of soil and plants in the vicinity of a lead zinc mine, Korea. - Applied Geochemistry 9: 11-53.

[22] Kabata-Pendias, A., Pendias, H. (1992): Trace elements in soils and plants. $-2^{\text {nd }}$ Edn., CRC Press, Florida, USA. p. 365.

[23] Kuboi, T., Noguchi, A., Yazaki, J. (1986): Family dependent cadmium accumulation characteristics in higher plants. - Plant and Soil 92: 405-415.

[24] Lindsay, W.L. (1972): Zinc in soils and plant nutrition. - In: Advance in Agronomy, (Ed.)., N. C. Brady 24: 147-186. 
[25] Lombi, E., Zhao, F.J., Dunham, S.J., Mac Grath, S.P. (2001): Phytoremediation of heavy metal contaminated soils: Natural hyperaccumulation versus chemically enhanced phytoextraction. - Journal of Environmental Quality 30(6): 1919-1926.

[26] Luo, Y., Rimmer, D.L. (1995): Zinc-copper interaction affecting plant growth on a metalcontaminated soil. - Environmental Pollution 88(10): 79-93.

[27] Ma, L.Q., Komar, K.M., Tu, C. Zhang, W. (2001): A fern that hyperaccumulates arsenic. - Nature 409: 579.

[28] O'Connor, C.S., Leppi, N.W., Edwards, R., Sunderland, G. (2003): The combined use of electro-kinetic remediation and phytoremediation to decontaminate metal-polluted soils: laboratory-scale feasibility study. - Environmental Monitoring Assessment 84(1-2) : 141158.

[29] O'Keeffe, J., Bendell-Young, L.I. (2002): Uptake of cadmium by the invasive perennial weeds Ranunculus repens and Geranium robertianum under laboratory conditions. Journal of Environmental Monitoring 4: 413-416.

[30] Prasad, M.N.V., Strzalka, K. (1999): Impact of heavy metals on Photosynthesis. - In: Heavy metal stress in plants: From molecules to ecosystems (ed.)., M.N.V. Prasad and J. Hagemeyer. Springer-Verlag. Berlin, Heidelberg, New York. p. 117-128.

[31] Raskin, L., Ensley, B.D. (2000): Phytoremediation of toxic metals using plants to clean up the environment. - John Wiley and Sons Incorporation, New York.

[32] Rosselli, W., Keller, C., Boschi, K. (2003): Phytoextraction capacity of tree growing on metal contaminated soil. - Plant and Soil 272: 256-265.

[33] Samiullah Khan, Nazar Khan, N. (1983): Influence of lead and cadmium on the growth and nutrient concentration of tomato (Lycopersicum esculentum) and egg-plant (Solanum melongena). - Plant and Soil 74: 387-394.

[34] Sharma, H.C., Rao, D.N. (1985): Responses of Phaseolus aureus Plants to So2 and HF Pollutants, Perspectives in Environmental Botany. - p. 131-150

[35] Sims, J.T., Heckendorn, S.E. (1991): Methods of Soil Analysis. - University of Delaware, College of Agricultural Sciences, New York. p. 1-117.

[36] Stewart, E.A., Grimshaw, M., Parkinson, J.A., Quarmby, C. (1974): Chemical analysis of ecological materials. - Blackwell Scientific Publications, Osney Mead, Oxford. p.1-234.

[37] Sun, T.H., Zhou, Q.X., Li, P.J. (2001): Pollution ecology. - Beijing, Science Press.

[38] Turgut, C., Pepe, M.K., Cutright, T.J. (2004): The effect of EDTA and citric acid on phytoremediation of $\mathrm{Cd}, \mathrm{Cr}$, amd $\mathrm{Ni}$ from soil using Helianthus annuus. - Environmental Pollution 131(1): 147-154.

[39] Wei Shuhe, Zhou Qixing, Wang Xin, Zhang Kaisong, Guo Guanin, Ma lena Qiying (2005): A newly - discovered Cd- hyperaccumulator Solanum nigrum L. - Chinese Science Bulletin 50(1): 33-38.

[40] Wei, S.H., Zhou, Q.X. (2004): Identification of weed species with hyperaccumulative characteristics of heavy metals. - Progress in Natural Science 14(6): 495-503.

[41] Wei, S.H., Zhou, Q.X., Wang, X. (2004): Potential of weed species applied to remediation of soils contaminated with heavy metal. - Journal of Environmental Science (China) 16(5): 868-873.

[42] Xian, X. (1989): Effects of chemical forms of cadmium zinc and lead in polluted soils on their uptake by cabbage plant. - Plant and Soil 113: 257-264.

[43] Xian, X., Shokohifard, G. (1989): Effect of pH on chemical forms and plant availability of cadmium, zinc and lead in polluted soils. - Water, Air and Soil Pollution 45: 265-273.

[44] Yu-Hong Su, Youn-Guan Zhu (2005): Influence of lead on atrazine uptake by rice (Oryza sativa L.) seedlings from nutrient solution. - Environmental Science and Pollution Research 12(1): 21-27.

[45] Zayed, A., Gowthaman, S., Terry, N. (1998): Phytoaccumulation of trace elements by wetland plants: I. Duckweed. - Journal of Environmental Quality 27: 715-721. 
[46] Zhou, Q.X., Cheng, Y., Zhang, Q.R. (2004): Quantitative analyses of relationships between ecotoxicological effects and combined pollution. - Science in China, Series C. 47(4): 332-339.

[47] Zhou, Q.X., Song, Y.F. (2004): Remediation of contaminated soils principles and methods. - Beijing, Science Press. 